\title{
Role of Topical Heparin in Treatment of Burn at Tertiary Care Hospital in Western Rajasthan
}

\author{
Dharmveer Jajra ${ }^{\oplus 1}$, Sanjay Lodha ${ }^{\circledR 2}$, Ashok Kumar ${ }^{\circledR 3}$, Diwan Singh Jakhar ${ }^{\oplus 1}$, Joginder Singh ${ }^{2}$ \\ ${ }^{1}$ Assistant Professor, Department of General Surgery, Sardar Patel Medical College, Bikaner, Rajasthan, India, ${ }^{2}$ Resident, Department of General Surgery, Sardar Patel \\ Medical College, Bikaner, Rajasthan, India, ${ }^{3}$ Associate Professor, Department of General Surgery, Sardar Patel Medical College, Bikaner, Rajasthan, India.
}

\section{Abstract}

Background: Heparin is a multifaceted compound with uses not only as an anticoagulant, but also as an anti-inflammatory, anti-allergenic, anti-histaminic, anti-serotonin, anti-proteolytic and neoangiogenic agent. The aim of the study was to study the effect of topical heparin in the management of burns in terms of morbidity, mortality \& safety. Subjects and Methods: A hospital based RCT with total duration of 16 months from June, 2018 to September, 2019 with 100 patients (age between 15-45 years, burns from 20-60\%, with less than 48 hours duration), randomly enrolled into 2 groups, after initial resuscitative measures, 50 cases receiving Topical Heparin treatment, 50 controls receiving conventional treatment ( $1 \%$ silver sulphadiazine) with i.v. antibiotics, after explaining the study objectives and taking informed written consent. Data analysis was performed using Epi Info software. Results: Patients treated with topical heparin experienced statistically significant $(p<0.05)$ improved pain relief, rapid healing, lesser complications and reduced duration of hospital stays. Conclusion: The current study demonstrates that topical heparin can improve clinical outcomes in the treatment of burn injury.

Keywords: Burns, Topical Heparin, Efficacy

Corresponding Author: Sanjay Lodha, Resident, Department of General Surgery, Sardar Patel Medical College, Bikaner, Rajasthan, India. E-mail: rohingarg99@gmail.com

\section{Introduction}

The history of treatment of burns is over 3500 years old. First evidence was found in cave paintings of Neanderthal man. In India with a population of over 1 billion, $70-80$ thousand burn admissions occur annually. ${ }^{[1]}$ Also commonest age group afflicted being the productive age group pose a problem to society being the income generating group. Significant breakthrough took place in the advanced countries in terms of reducing mortality and controlling morbidity. This necessitates the development of newer methods of management within our means to reach the common end point of reducing morbidity and mortality. ${ }^{[2]}$

In this regard, heparin has been introduced because of its research proven role in burn wound management. ${ }^{[3]}$ Multiple mechanisms explain the role of heparin in burns when used topically. Firstly, heparin may work partially because of anti-inflammatory activity. The effects may directly or indirectly mediate on many factors producing inflammation. ${ }^{[4]}$ The mechanism of action may also include influencing monocyte, T-cell and neutrophil activity, nitric oxide production, chemokine and cytokine activity, complement activ- ity, platelet activation and aggregation, and smooth muscle cell proliferation. ${ }^{[5]}$ Second, heparin can restore blood flow in a shorter time and revascularize ischemic tissue, through enhanced vascular growth. ${ }^{[6]}$ Possible mechanisms of this action are the inhibition of selectin-mediated cell-cell interactions, heparinase inhibition, binding of proangiogenic growth factors and stimulation of tissue factor pathway inhibitor release. ${ }^{[7]}$ Third, wound healing is affected by enzymes such as elastase, cathepsin $\mathrm{G}$, and proteinases, which degrade the extracellular matrix, growth factors and further recruit neutrophils to the wound area. Heparin and related molecules could inhibit the function of these cells through electrostatic interactions and enhance the healing. ${ }^{[8,9]}$

This study was conducted to study the role of topical heparin in the management of burns and to validate its efficacy and safety in Tertiary care hospital in western Rajasthan.

\section{Subjects and Methods}

After obtaining approval from the Institutional Ethical Committee, the study was conducted in Department of Surgery, S. P. Medical College and associated group of hospitals, Bikaner. 
It is a hospital-based randomized control trial with total duration of 16 months from June, 2018 to September, 2019. Study groups are the patients admitted in our hospital burn ward with age group between $15-45$ years \& having burns ranging from $20-60 \%$, with less than 48 hours duration. Patients with bleeding diathesis, pregnant ladies, coagulation disorders and allergic to heparin were excluded from study group.

\section{Heparin Administration Method}

$20.8 \mathrm{ml}$ of $5000 \mathrm{IU} / \mathrm{ml}$ (International Units per $\mathrm{ml}$ ) of heparin solution was added to $500 \mathrm{ml}$ of physiological normal saline solution in an intravenous fluid bottle to make a total 520.8 $\mathrm{ml}$ of $200 \mathrm{IU} / \mathrm{ml}$ concentration heparin sodium solution. The dose of heparin required for topical application was calculated to be $100,000 \mathrm{IU} / 15 \%$ burn surface area (BSA) per day in 3-4 divided doses. The medication was applied to the burnt surface drop by drop with a $50 \mathrm{ml}$ syringe, until the pain was relieved, repeated for 2-4 times until blanching occurred. Beginning on the 2 nd day, heparin was applied twice a day, using a diminishing quantity for 1 week.

Blisters were rinsed with heparin solution via hypodermic syringe and were not de-roofed. Blood was drawn to test for bleeding time, clotting time, and activated partial thromboplastin time, in addition to routine blood investigations.

Relief of pain was recorded by a visual analog scale, healing of wounds, dose of heparin, complications, mortality and duration of hospital stay were reported and analyzed. This was a single blinded study that was approved by the Ethics Committee of the Institute. Written informed consent was obtained from the patients or guardians.

\section{The Various Parameters Measured Were}

- I.V. Fluid requirement (in liters)

- Severity of pain (Visual Analog Scale) and analgesic requirement (doses/day)

- Morbidity pattern (in terms of hospital stay)

Data analysis was performed using Microsoft Excel sheet and Epi Info software of WHO-CDC.

\section{Results}

100 consecutive burns patients were selected over a period of sixteen months based on inclusion and exclusion criteria. Of them, fifty were treated with topical heparin therapy (Group $\mathrm{H}$ ) and the other fifty patients by conventional methods (Group C). After initial resuscitative measures patients were allotted to conventional therapy ( $1 \%$ silver sulfadiazine) to ' $\mathrm{C}$ ' group or Heparin therapy to ' $\mathrm{H}$ ' group. Results of both the groups were compared with various variables to know the effectiveness of topical heparin therapy.

Of these $68 \%$ were between $26-45$ years and $32 \%$ between 15 25 years. There is no significant difference in age among these

\begin{tabular}{|c|c|c|c|}
\hline Variable & $\begin{array}{l}\text { Heparin } \\
\text { Group } \\
(\mathbf{N H}=\mathbf{5 0})\end{array}$ & $\begin{array}{l}\text { Control } \\
\text { Group } \\
(\mathbf{N C}=\mathbf{5 0})\end{array}$ & P Value \\
\hline \multicolumn{3}{|c|}{ Age(in years) } & 0.970 \\
\hline $15-25$ & $15(30 \%)$ & $17(34 \%)$ & \\
\hline $26-35$ & $16(32 \%)$ & $16(32 \%)$ & \\
\hline $36-45$ & $19(38 \%)$ & $17(34 \%)$ & \\
\hline SEX & & & 0.838 \\
\hline Male & $30(60 \%)$ & $30(60 \%)$ & \\
\hline Female & $20(40 \%)$ & $20(40 \%)$ & \\
\hline Residence & & & 0.835 \\
\hline Rural & $32(64 \%)$ & $32(64 \%)$ & \\
\hline Urban & $18(36 \%)$ & $18(36 \%)$ & \\
\hline \multicolumn{3}{|c|}{ Mode of burn } & 0.358 \\
\hline $\begin{array}{l}\text { Flame } \\
\text { Burn }\end{array}$ & $39(78 \%)$ & $43(86 \%)$ & \\
\hline $\begin{array}{l}\text { Electric } \\
\text { Burn }\end{array}$ & $5(10 \%)$ & $1(2 \%)$ & \\
\hline $\begin{array}{l}\text { Scald } \\
\text { Burn }\end{array}$ & $6(12 \%)$ & $5(10 \%)$ & \\
\hline Acid Burn & $0(0 \%)$ & $1(2 \%)$ & \\
\hline \multicolumn{3}{|l|}{ TBSA $\%$} & 0.134 \\
\hline $15-20$ & $5(10 \%)$ & $3(6 \%)$ & \\
\hline $21-25$ & $3(6 \%)$ & $2(4 \%)$ & \\
\hline $26-30$ & $12(24 \%)$ & $4(8 \%)$ & \\
\hline $31-35$ & $5(10 \%)$ & $10(20 \%)$ & \\
\hline $36-40$ & $13(26 \%)$ & $10(20 \%)$ & \\
\hline $41-45$ & $3(6 \%)$ & $4(8 \%)$ & \\
\hline $46-50$ & $1(2 \%)$ & $8(16 \%)$ & \\
\hline $51-55$ & $1(2 \%)$ & $1(2 \%)$ & \\
\hline $56-60$ & $7(14 \%)$ & $8(16 \%)$ & \\
\hline \multicolumn{3}{|c|}{ Degree of Burn } & 0.644 \\
\hline Superficial & $39(78 \%)$ & $36(72 \%)$ & \\
\hline Deep & $11(22 \%)$ & $14(28 \%)$ & \\
\hline
\end{tabular}

two groups. In both groups, there is equal distribution of males and females and study is male dominant (60\% males and $40 \%$ females). There were more patients from rural areas (64\%). In both groups, maximum patients associated from flame burns. Among $\mathrm{H}$ group, $60 \%$ of patients had $26-40 \%$ burns. Similarly among $\mathrm{C}$ group patients $54 \%$ of patients had $26-40 \%$ burns. In both groups approx. $3 / 4^{\text {th }}$ proportion were superficial burn. All the demographic parameters are not significant in the groups. 
Table 2: Distribution of patients by requirements of IV fluids, Analgesic Requirement, Duration of Hospital stay, Treatment outcome and Contractures after 2 months

\begin{tabular}{|c|c|c|c|}
\hline Variable & $\begin{array}{l}\text { Heparin } \\
\text { Group } \\
(\mathbf{N H}=\mathbf{5 0})\end{array}$ & $\begin{array}{l}\text { Control } \\
\text { Group } \\
(\mathrm{NC}=\mathbf{5 0})\end{array}$ & P Value \\
\hline \multicolumn{3}{|c|}{ I.V. Fluid Requirement in 1st week } & $0.001 *$ \\
\hline $\begin{array}{l}\text { No. of pts. } \\
\text { Adminis- } \\
\text { tered }\end{array}$ & $36(72 \%)$ & $45(90 \%)$ & \\
\hline $\begin{array}{l}\text { Amount } \\
\text { (liters) } \\
\text { Mean } \pm \text { SD }\end{array}$ & $10.04 \pm 4.15$ & $18.42 \pm 12.59$ & \\
\hline \multicolumn{3}{|c|}{ Analgesia Requirement (times/day) } & $0.036^{*}$ \\
\hline $1-2$ & $50(100 \%)$ & $16(32 \%)$ & \\
\hline $3-4$ & $0(0 \%)$ & $34(68 \%)$ & \\
\hline \multicolumn{2}{|c|}{ DOHS (Days) } & & $0.018^{*}$ \\
\hline 8-14 days & $34(68 \%)$ & $14(28 \%)$ & \\
\hline 15-21 days & $9(18 \%)$ & $23(46 \%)$ & \\
\hline 22-28 days & $3(6 \%)$ & $6(12 \%)$ & \\
\hline 29-60 days & $2(4 \%)$ & $6(12 \%)$ & \\
\hline$>60$ days & $0(0 \%)$ & $1(2 \%)$ & \\
\hline \multicolumn{3}{|c|}{ Treatment Outcome } & $0.0437 *$ \\
\hline Discharged & $46(92 \%)$ & $36(72 \%)$ & \\
\hline Expired & $4(8 \%)$ & $14(28 \%)$ & \\
\hline \multicolumn{3}{|c|}{ Contractures after 2 months } & $0.001 *$ \\
\hline Yes & $2(4 \%)$ & $12(24 \%)$ & \\
\hline No & $44(88 \%)$ & $24(48 \%)$ & \\
\hline
\end{tabular}

There is $72.00 \%$ needed IV fluid in heparin group whereas $90.00 \%$ needed IV fluid in control group. Association of both groups with amount of IV fluids found to be statistically significant $(\mathrm{p}<0.05)$.

In heparin group all patients needed analgesic (injection tramadol $100 \mathrm{mg} / 2 \mathrm{ml}$ ) for $1-2$ times per day. None of the case required analgesic more than 2 times a day. In control group approx. 2/3rd proportion needed analgesic for 3-4 times a day. Association of both groups with analgesic use was statistically significant $(\mathrm{p}<0.05)$.

In heparin group maximum $68.00 \%$ had 8-14 days hospital stay whereas no patient had hospital stay more than 60 days. In control group maximum $46.00 \%$ had $15-21$ days hospital days whereas minimum $2.00 \%$ had more than 60 days of hospital stay. Association of hospital stay with both groups was found to be statistically significant ( $\mathrm{p}<0.05)$.

Maximum 92.00\% were discharged whereas $8.00 \%$ were expired in heparin group. Maximum $72.00 \%$ were discharged in control group whereas $28.00 \%$ were expired. Association of both groups with treatment outcome was statistically significant $(\mathrm{p}<0.05)$.

Only $4.00 \%$ in heparin group had contracture whereas $24.00 \%$ of control group had contractures. Association of presence of contractures at follow up visit after 2 months with both groups was statistically significant $(\mathrm{p}<0.05)$.

Table 3: Distribution of Heparin group according to their Heparin dose requirement (Lac IU)

\begin{tabular}{|c|c|c|c|}
\hline $\begin{array}{l}\text { Total Body } \\
\text { Surface } \\
\text { Area (\%) }\end{array}$ & $\begin{array}{l}\text { Heparin } \\
\text { Group }\left(\mathrm{N}_{\mathrm{H}}\right. \\
=\mathbf{5 0})\end{array}$ & $\begin{array}{l}\text { Heparin } \\
\text { Dose(Lac } \\
\text { IU) Mean }\end{array}$ & $P$ value \\
\hline & Frequency & & \\
\hline $15-20$ & $5(10 \%)$ & $3.7 \pm 0.91$ & \\
\hline $21-25$ & $3(6 \%)$ & $4.43 \pm 1.16$ & \\
\hline $26-30$ & $12(24 \%)$ & $5.18 \pm 0.56$ & \\
\hline $31-35$ & $5(10 \%)$ & $5.68 \pm 1.13$ & \\
\hline $36-40$ & $13(26 \%)$ & $7.63 \pm 1.78$ & \\
\hline $41-45$ & $3(6 \%)$ & $7.76 \pm 2.12$ & \\
\hline $46-50$ & $1(2 \%)$ & $9.8 \pm 0.0$ & \\
\hline $51-55$ & $1(2 \%)$ & $10.0 \pm 0.0$ & \\
\hline $56-60$ & $7(14 \%)$ & $\begin{array}{l}10.17 \quad \pm \\
1.36\end{array}$ & \\
\hline Total & 50 & $100.00 \%$ & \\
\hline
\end{tabular}

Maximum 10.17 \pm 1.36 (Lac IU) heparin was consumed by $14 \%$ whereas minimum $3.7 \pm 0.91$ (Lac IU) heparin was consumed by $10 \%$ of heparin group. Maximum $26.00 \%$ of heparin group had consumed 7.63 \pm 1.78 (Lac IU) heparin. Association of TBSA and Heparin consumed was found to be statistically significant $(\mathrm{p}<0.05)$.

Table 4: Distribution of Heparin group and Control group according to VAS scale scoring on day 1 and day 7 of treatment

\begin{tabular}{|c|c|c|c|c|}
\hline \multirow[t]{2}{*}{$\begin{array}{l}\text { VAS } \\
\text { Scale }\end{array}$} & \multicolumn{2}{|c|}{$\begin{array}{l}\text { Heparin Group }\left(\mathrm{N}_{\mathrm{H}}\right. \\
=50)\end{array}$} & \multicolumn{2}{|c|}{$\begin{array}{l}\text { Control Group }\left(\mathbf{N}_{\mathbf{C}}\right. \\
=50)\end{array}$} \\
\hline & Day 1 & Day 7 & Day 1 & Day 7 \\
\hline $\mathrm{MEAN} \pm \mathrm{S}$ & $6.87 \pm 2.46$ & $3.15 \pm 0.92$ & $7.95 \pm 0.95$ & $7.71 \pm 1.58$ \\
\hline$P$ value & $0.001 * *$ & & $0.360 \mathrm{NS}$ & \\
\hline
\end{tabular}

\section{Discussion}

Burns are painful wounds. The sufferings and squeal of burn victims are disastrous. Burn sequels affect life quality and produce longstanding emotional and social impacts in the patient's life. The development of new treatment resources could modify this picture. In this study, a new treatment 


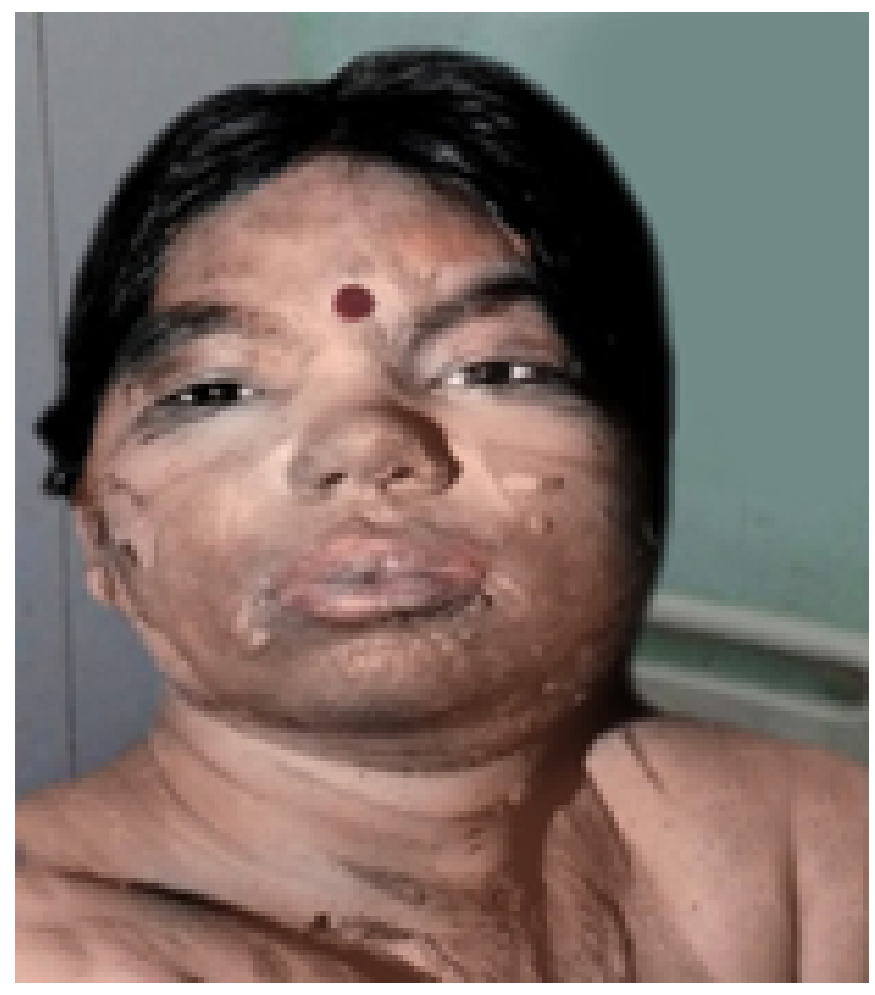

Figure 1: Photograph showing edema over face especially over left side (at the time of admission)

approach using topical heparin was used to assess the efficacy and safety of topical heparin therapy in burns.

The numbers, ages, gender of the patients, as also the mode of burn was comparable in both the groups which were insignificant.

In our study, average hospital stay of control group is 19.6 days while in H-group average hospital stay is 14.48 days $(p=0.018)$. Masoud $\mathrm{M}$ et al, ${ }^{[10]}$ found average hospital stay of 18.3 days in the $\mathrm{C}$-group while patients belonging to the $\mathrm{H}$ group had an average hospital stay of 12.3 days $(\mathrm{P}<0.05)$. M. Swatantra Bharathi et al, ${ }^{[11]}$ found average duration of hospital stay in $\mathrm{C}$ group is 34.72 days and in $\mathrm{H}$ group it was 21.36 days $(\mathrm{p}<0.001)$.

In our study, there was $8 \%$ mortality in heparin group whereas $28.00 \%$ mortality was observed in control group. Association of both groups with treatment outcome was statistically significant $(\mathrm{p}<0.05)$. Venakatachalapathy TS et al, ${ }^{[12]}$ observed mortality in $\mathrm{C}$ group (10\%) but not in $\mathrm{H}$ group. Zayas GJ et al, ${ }^{[13]}$ observed increase in survival with heparin from $11 \%$ to $60 \%$ and, therefore, the decrease in mortality from $89 \%$ to $40 \%$ were significant $(\mathrm{p}<0.04)$.

In our study, the heparin patients complained of less pain and received less analgesia doses than the control patients (i.e.

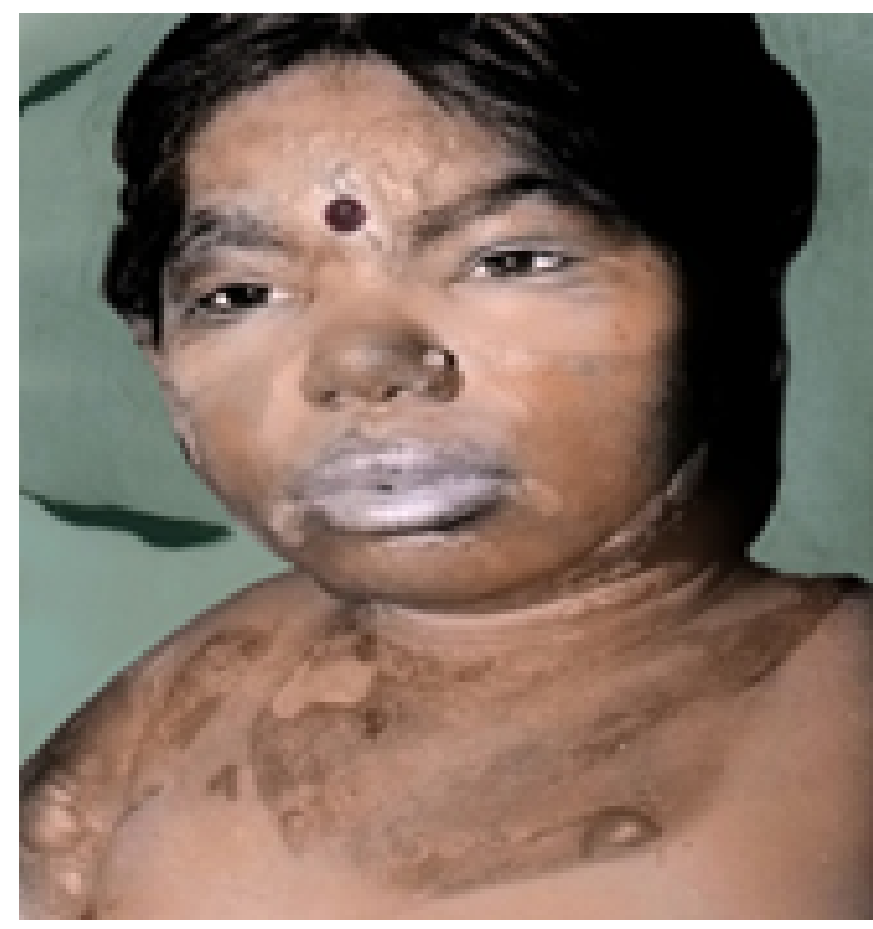

Figure 2: Photograph showing significant elimination of edema, after 3 days of topical heparin therapy

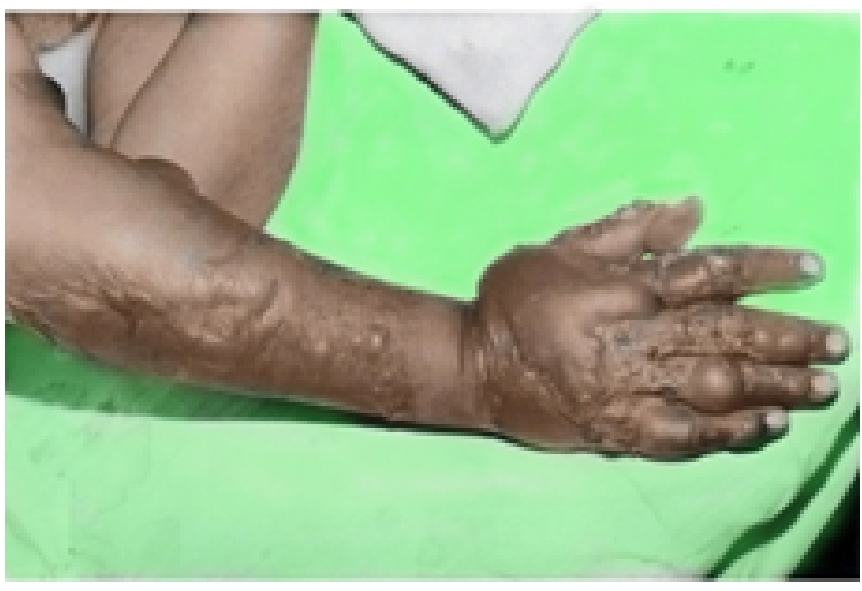

Figure 3: Photograph showing burn of right arm with edema and blisters on admission 


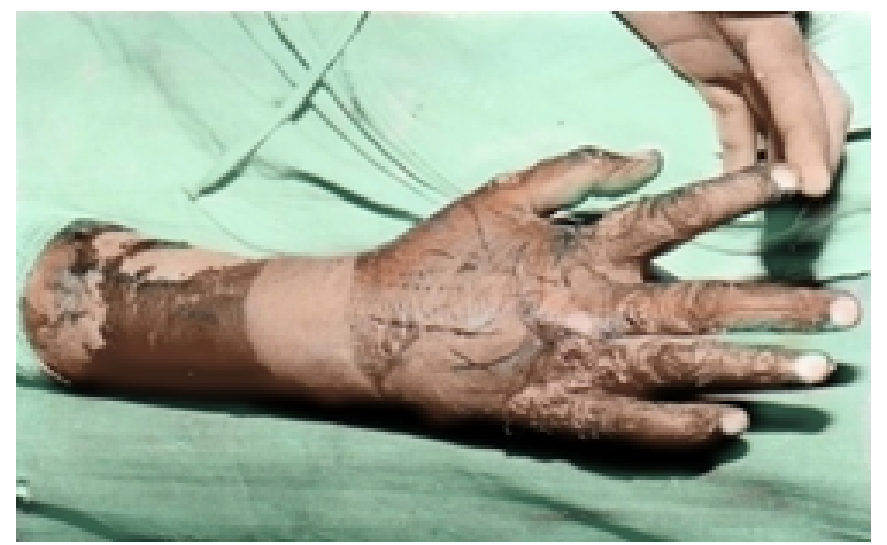

Figure 4: Photograph showing healing of burn after 7 days

$6.56 \pm 4.55$ in $\mathrm{H}$ group vs. $16.70 \pm 7.83$ in $\mathrm{C}$ group). Association of both groups with analgesic use was statistically significant $(\mathrm{p}<0.05)$. Barretto MG et al, ${ }^{[14]}$ found that group H demanded less analgesic medications (11.83+/- 9.38 per patient against $33.35+/-20.63$ for the $\mathrm{C}$ group, $\mathrm{p}<0.01)$.

Our study found that there is a significant difference in fluids infused between C-group: 20.46 liters in $45 \mathrm{C}$ patients vs. 13.94 liters in $36 \mathrm{H}$ patients $(\mathrm{p}<0.05)$. Venakatachalapathy TS et al, ${ }^{[12]}$ also found that significantly less intravenous fluid was infused in H: 33.5 liters in $39 \mathrm{H}$ patients vs. 65 liters in 41 C patients, i.e. nearly 50\% less $(\mathrm{p}<0.04)$.

In our study, maximum $10.71 \pm 1.36$ (Lac IU), heparin was consumed by $14 \%$ whereas minimum $3.7 \pm 0.91$ (Lac IU) heparin was consumed by $10 \%$ of heparin group. As TBSA increased in our study, the heparin requirement of $\mathrm{H}$ group increased accordingly. Association of TBSA and Heparin consumed was found to be statistically significant $(\mathrm{p}<0.05)$.

In our study, heparin group had lesser prevalence of contractures (4\% vs. $24 \%$ ). M. Swatantra Bharathi et al, ${ }^{[11]}$ found one contracture release later after discharge in $\mathrm{C}$ group while in $\mathrm{H}$ group none had any post burn contracture.

When VAS scale on day 1 and day 7 were observed in both groups of our study, the control group was observed with much higher VAS values as compared to Heparin group on day 7 (i.e.7.71 \pm 1.58 in control vs. $3.15 \pm 0.92$ in heparin group) and the difference was statistically highly significant $(\mathrm{p}<0.05)$. Sobia Manzoor et al, ${ }^{[15]}$ found mean pain score was also lower in the heparin group ( $3 \pm 1$ in heparin vs. $7 \pm 1$ in control group).

\section{Conclusion}

From our study, it was concluded that topical heparin is an effective pharmacological agent to overcome immediate post burn problems i.e. pain, hypovolemia. It decreases the duration of hospital stay, analgesic use and requirement of I.V. fluid. It decreases the morbidity in burn i.e. post burn contractures. There was less number of mortality in heparin patients.

By the results of our preliminary study, it was not being said emphatically that heparin is any panacea for patients of burns but it is definitely a good supportive measure, if added.

Longer clinical trials are needed before it can be recommended for routine use in burns.

\section{Acknowledgements}

Authors would like to thank Dr. Gautam Luniya for statistical help.

\section{References}

1. Saliba MJ. Heparin in the treatment of burns: a review. Burns. 2001;27(4):349-358. Available from: https://dx. doi.org/10.1016/s0305-4179(00)00130-3. doi:10.1016/s03054179(00)00130-3.

2. Rayes A, Astiazaran JA, Chavez CC, Jaramilla F, Saliba MJ. Burns treated with and without heparin: Controlled use in a thermal disaster. Ann Burns Fire Disasters. 2001;14:183-191.

3. $\mathrm{Lu} \mathrm{J}, \mathrm{Xu} \mathrm{T}$. Heparin for the Treatment of Burns. Intervent Prot Cochrane Coll. 2011;2:45-54.

4. Saliba MJ. The effects and uses of heparin in the care of burns that improves treatment and enhances the quality of life. Acta Chir Plast. 1997;39:13-19.

5. Tyrrell DJ, Horne AP, Holme KR, Preuss JM, Page CP. Heparin in infl ammation: potential therapeutic applications beyond anticoagulation. Adv Pharmacol. 1999;46:151-208.

6. Saliba MJ. Heparin in the treatment of burns: a review. Burns. 2001;27(4):349-58. doi:10.1016/s0305-4179(00)00130-3.

7. Elsayed E, Becker RC. The impact of heparin compounds on cellular inflammatory responses: A construct for future investigation and pharmaceutical development. J Thromb Thrombolysis. 2003;15:11-19. doi:10.1023/a:1026184100030.

8. Peplow PV. Glycosaminoglycan: a candidate to stimulate the repair of chronic wounds. Thrombosis Haemostasis. 2005;94(07):4-16. Available from: https://dx.doi.org/10.1160/ th04-12-0812. doi:10.1160/th04-12-0812.

9. Wang J, Zheng H, Qiu X, Kulkarni A, Fink LM, Hauer-Jensen M. Modulation of the intestinal response to ionizing radiation by anticoagulant and non-anticoagulant heparins. Thrombosis Haemostasis. 2005;94(11):1054-1059. Available from: https:// dx.doi.org/10.1160/th05-05-0330. doi:10.1160/th05-05-0330.

10. Masoud M, Wani AH, Darzi MA. Topical heparin versus conventional treatment in acute burns: A comparative study. Indian J Burns. 2014;22(1):43-43. Available from: https://dx.doi.org/ 10.4103/0971-653x.147002. doi:10.4103/0971-653x.147002.

11. Bharathi M, Sudhakar PV. Role of topical heparin therapy in thermal burns. Int J Cont Med Res. 2017;4(11):2235-2239. 
12. Venakatachalapathy TS, Kumar M, Saliba S, J M. A comparative study of burns treated with topical heparin and without heparin. Ann Burns Fire Disasters. 2007;20(4):189198.

13. Zayas GJ, Bonilla AM, Saliba MJ. Heparin reduced mortality and sepsis in severely burned children. Ann Burns Fire Disasters. 2007;20(1):29-34.

14. Barretto MG, Mda C, Serra G, Afiune MC, Praxedes JB, Pagani HE, et al. Comparative study of conventional and topical heparin treatments for burns analgesia. Rev Assoc Med Bras. 2010;56(1):51-56.

15. Manzoor S, Khan FA, Muhammad S, Qayyum R, Muhammad I, Nazir U, et al. Comparative study of conventional and topical heparin treatment in second degree burn patients for burn analgesia and wound healing. Burns. 2019;45(2):379386. Available from: https://dx.doi.org/10.1016/j.burns.2018. 05.010. doi:10.1016/j.burns.2018.05.010.
Copyright: (C) the author(s), 2020. It is an open-access article distributed under the terms of the Creative Commons Attribution License (CC BY 4.0), which permits authors to retain ownership of the copyright for their content, and allow anyone to download, reuse, reprint, modify, distribute and/or copy the content as long as the original authors and source are cited.

How to cite this article: Jajra D, Lodha S, Kumar A, Jakhar DS, Singh J. Role of Topical Heparin in Treatment of Burn at Tertiary Care Hospital in Western Rajasthan. Acad. J Surg. 2020;3(1):110115.

DOI: dx.doi.org/10.47008/ajs/2020.3.1.24

Source of Support: Nil, Conflict of Interest: None declared. 